\title{
Peces criptobentónicos en el Parque Nacional Natural Uramba Bahía Málaga (Colombia), Pacífico Oriental Tropical
}

\section{Cryptobenthic fishes in the Uramba National Natural Park Bahía Málaga (Colombia), Tropical Eastern Pacific}

\author{
Gustavo Adolfo Castellanos-Galindo ${ }^{1,2}$, Diana Medina-Contreras ${ }^{1,3}$, Juan Felipe Lazarus ${ }^{1,4} *$ y Jaime Ricardo Cantera-Kintz \\ $\begin{array}{llll}\text { (D) } 0000-0002-7849-5205 & \text { (D) } 0000-0002-4156-0755 & \text { (DD } 0000-0003-2121-3569 & \text { (D) } 0000-0002-4010-298 x\end{array}$ \\ 1. Departamento de Biología, Facultad de Ciencias Naturales y Exactas, Universidad del Valle, Cali, Colombia. jaime.cantera@correounivalle.edu.co \\ 2. Leibniz Centre for Tropical Marine Research (ZMT),Bremen, Alemania.gustavoa80@yahoo.com \\ 3. Instituto Politécnico Nacional, Centro Interdisciplinario de Ciencias Marinas, La Paz, México.dmedinac1900@alumno.ipn.mx \\ 4. Departamento de Ciencias Naturales y Matemáticas, Facultad de Ingeniería y Ciencias, Pontificia Universidad Javeriana, Cali, Colombia. \\ jflazarus@gmail.com* \\ * Autor para correspondencia.
}

\section{RESUMEN}

$\mathrm{L}$ os peces criptobentónicos contribuyen de manera significativa a la dinámica trófica de los ecosistemas costeros. Este estudio tuvo como objetivo determinar la composición de esta comunidad y comprobar si su estructura difiere temporal y espacialmente en el Parque Nacional Natural Uramba Bahía Málaga (Pacífico Oriental Tropical). Los peces se recolectaron utilizando sustratos artificiales en tres zonas, entre junio de 2008 y agosto de 2009. Se registraron 26 especies, pertenecientes a 11 familias. Gobiidae y Labrisomidae fueron las familias más representativas (especies: $34,6 \%$ e individuos: $66 \%$ ). La riqueza y abundancia aumentó en un gradiente del interior hacia el exterior del parque. Utilizando estadística multivariada, se identificó un patrón espacial en la estructura de la comunidad, con localidades internas significativamente diferentes de las medias y externas. Cerdale ionthas, Gobiosoma seminudum, Starksia fulva y Gobulus hancocki fueron responsables de esta diferenciación (contribución $>59 \%$ ). El uso de sustratos artificiales para tomar muestras de peces criptobentónicos demostró ser una forma eficiente de identificar una parte de la ictiofauna que no había sido identificada mediante técnicas de muestreo tradicionales y también fue útil para comparar la variabilidad espacial de esta comunidad. La comparación con comunidades de peces criptobentónicos en otras regiones biogeográficas indica que, debido a la baja riqueza de especies en el Pacífico Oriental Tropical, estas comunidades tanto en Colombia como en México muestran baja redundancia funcional y considerables diferencias en sus preferencias tróficas.

PALABRAS CLAVE: ictiofauna críptica, Gobiidae, Labrisomidae, ecología estuarina, arrecifes rocosos

\section{ABSTRACT}

$\mathrm{C}$ ryptobenthic fishes contribute significantly to the trophic dynamics of coastal ecosystems. This study aimed at determining the composition of this assemblage and testing if its structure differs temporally and spatially in the Uramba National Natural Park Bahía Málaga (Tropical Eastern Pacific). Fish assemblages were collected using artificial traps in three zones, between June 2008 and August 2009. Twenty-six fish species belonging 11 families were recorded. Gobiidae and Labrisomidae were the most representative families (species: $34.6 \%$ and individuals: $66 \%$ ). Species richness and abundance increased in a gradient from the interior to the exterior of the park. Using multivariate statistic techniques, a spatial pattern in assemblage structure was identified with inner zone being significantly different from the mid and outer zones. Cerdale ionthans, Gobiosoma seminudum, Starksia fulva, and Gobulus hancocki were mainly responsible for this differentiation ( $>59 \%$ contribution). The use of artificial habitats to sample cryptobenthic fish proved to be an efficient way to identify an overlooked part ichthyofauna using traditional sampling techniques and was also useful to compare the spatial variability of these assemblages. Comparisons with cryptobenthic fish assemblages in other biogeographic regions indicate that, due to their low species richness in the Tropical Eastern Pacific, these assemblages in both Colombia and Mexico show low functional redundancy and considerable differences in their predominant trophic modes.

KEYWORDS: cryptic ichthyofauna, Gobiidae, Labrisomidae, estuarine ecology, rocky reefs 


\section{INTRODUCCIÓN}

Los peces criptobentónicos pueden ser definidos como "peces adultos de usualmente $<5 \mathrm{~cm}$ que son visualmente $y / o$ de comportamiento críptico, los cuales tienen una fuerte relación con el bentos" (Depczynski y Bellwood, 2003: 183). En fondos duros, como en los arrecifes de coral, estos pueden llegar a ser $\sim 50 \%$ de la abundancia de los peces, $\sim 40 \%$ del número de especies de peces y $35 \%$ del total de la biomasa íctica (Ackerman y Bellwood, 2000, 2002). La gran abundancia de larvas de peces criptobentónicos y el análisis del contenido estomacal de depredadores arrecifales sugieren que probablemente estos desempeñan un papel importante en la dinámica trófica de los arrecifes coralinos, al participar en el reciclaje de la biomasa derivada de la producción primaria a través de vías detríticas (Depczynski y Bellwood, 2003; Brandl et al., 2019). Por otra parte, análisis de isótopos estables $\left(\delta^{15} \mathrm{~N}\right)$ en zonas estuarinas tropicales señalan un nivel trófico medio y alto para este tipo de organismos, lo cual indicaría que se comportan como depredadores de microfauna bentónica (Medina-Contreras et al., 2018).

Las técnicas de muestreo utilizadas comúnmente, como los censos visuales, no permiten obtener información ecológica sobre las comunidades de peces criptobentónicos (Willis, 2001) debido al sesgo que se presenta hacia individuos con longitud total de $>5 \mathrm{~cm}$. Esta técnica suele subestimar la contribución de los peces criptobentónicos, por lo que se han realizado ajustes a los censos visuales para estudiar este grupo de organismos (Beldade y Gonçalves, 2007). En aguas turbias como en las zonas estuarinas cercanas a bosques de manglar, donde la visibilidad es reducida $(<1 \mathrm{~m})$, los censos visuales son poco prácticos. Por lo tanto, para muestrear esta comunidad en estos ambientes se han usado sustancias anestésicas e ictiocidas (v. g. Barletta et al., 2002). Estas sustancias tienen restricciones en su uso debido a su impacto ambiental; sin embargo, pueden brindar información precisa sobre inventarios de biodiversidad a escalas pequeñas de muestreo (Robertson y Smith-Vaniz, 2008). En el caso de áreas marinas protegidas, el uso de estas sustancias es restringido debido a que podrían afectar otros organismos que no hacen parte del grupo de estudio, así como los ecosistemas muestreados. Por esta razón, es necesario contar con métodos de muestreo alternativos, los cuales incluyen el uso de unidades estandarizadas que imitan las condiciones del sustrato (Zimmerman y Martin, 2004; Ransome et al., 2017). Estas unidades de muestreo se ubican en hábitats específicos y se recuperan después de un cierto período, recolectando peces y especies de invertebrados crípticos de una manera efectiva.

\section{INTRODUCTION}

Cryptobenthic fish can be defined as "adult fishes usually $<5 \mathrm{~cm}$ that are visually and/or cryptic in behavior, having a strong relationship with benthos" (Depczynski and Bellwood, 2003: 183). On hard bottoms, such as coral reefs, these can be $\sim 50 \%$ of the abundance of fish, $\sim 40 \%$ of the number of fish species, and $\sim 35 \%$ of the total fish biomass (Ackerman and Bellwood, 2000, 2002). The great abundance of cryptobenthic fish larvae and the analysis of the stomach contents of reef predators suggest that they probably play an essential role in the trophic dynamics of coral reefs, participating in the recycling of biomassderived from primary production through detrital pathways (Depczynski and Bellwood, 2003; Brandl et al., 2019). On the other hand, analysis of stable isotopes $\left(\delta^{15} \mathrm{~N}\right)$ in tropical estuarine zones indicate a medium and high trophic level for this type of organisms, which would indicate that they behave as predators of benthic microfauna (MedinaContreras et al., 2018).

Commonly used sampling techniques, such as visual censuses, do not allow obtaining ecological information on cryptobenthic fish communities (Willis, 2001) due to the bias towards individuals with a total length $>5 \mathrm{~cm}$. This technique tends to underestimate the contribution of cryptobenthic fish, so adjustments have been made to visual censuses to study this group of organisms (Beldade and Gonçalves, 2007). In turbid waters such as in estuarine areas near mangrove forests, where visibility is low $(<1 \mathrm{~m})$, visual censuses are impractical. Therefore, anesthetic and ichthyocides have been used to sample this community in these environments. (e.g. Barletta et al., 2002). These substances have restrictions in their use due to their environmental impact; however, they can provide accurate information on biodiversity inventories at small sampling scales (Robertson and Smith-Vaniz, 2008). In the case of marine protected areas, the use of these substances is restricted because they could affect other organisms that are not part of the study group, as well as the sampled ecosystems. For this reason, it is necessary to have alternative sampling methods, which include the use of standardized units that mimic the conditions of the substrate (Zimmerman and Martin, 2004; Ransome et al., 2017). These sampling units are located in specific habitats and recovered after a certain period, collecting fish and cryptic invertebrate species in an effective way. These devices can also be used to investigate settlement and recruitment events (Robertson et al., 1988; Glynn, 
Estos dispositivos también se pueden utilizar para investigar eventos de asentamiento y reclutamiento (Robertson et al., 1988; Glynn, 2006; Valles et al., 2006; Carassou et al., 2009; Mellin y Pontón, 2009).

Hasta el momento no existen estudios que hayan documentado la abundancia relativa de la comunidad de peces crípticos en los sistemas estuarinos del Pacífico Oriental Tropical (POT) y particularmente en la costa Pacífica de Colombia. Para la mayoría de las especies que conforman esta comunidad, la única información disponible está restringida a su descripción original, registros únicos y listas de especies de áreas específicas. Los estudios que abordan la ecología de los peces crípticos en el POT se han realizado en charcos intermareales y arrecifes coralinos en México y Colombia (Castellanos-Galindo et al., 2005, 2014; Balart et al., 2006; González-Cabello y Bellwood, 2009; Alzate et al., 2014). Los peces criptobentónicos del POT poseen una baja riqueza de especies comparada con otras áreas, lo que produce baja redundancia funcional entre las especies que componen estas comunidades (González-Cabello y Bellwood, 2009). Lo anterior hace referencia a que pocas especies desempeñan una misma función en el ecosistema (v. g. hábitos alimentarios) (Loreau, 2004), por lo que esta función es vulnerable a perturbaciones. Dichas características hacen que esta comunidad de organismos sea vulnerable tanto a impactos antropogénicos como ambientales.

En el presente trabajo se documenta por primera vez la comunidad de peces criptobentónicos en el área marina protegida Parque Nacional Natural Uramba Bahía Málaga (PNN Uramba). También se evalúa si la estructura de esta comunidad difiere temporal y espacialmente en este lugar.

\section{ÁREA DE ESTUDIO}

El PNN Uramba (3,953169 N-77,326456 W; Figura 1) es un área marina protegida (AMP) ubicada en la costa central del Pacífico colombiano. Esta bahía se formó durante eventos tectónicos en el Mioceno tardío-Holoceno (Martínez y López-Ramos, 2011). Tiene una extensión de 470,94 $\mathrm{km}^{2}$. Predominan condiciones estuarinas y se presentan profundidades promedio de 12-15 m. Además, alberga diversidad de hábitats que incluyen manglares, costas rocosas, planos lodosos, playas arenosas y fondos tanto blandos como duros (Cantera-Kintz et al., 2013). La precipitación anual es una de las mayores entre las áreas costeras del hemisferio occidental, con un promedio de $7236 \pm$ 2033 mm entre 1969 y 2015 (estación n. ${ }^{\circ}$ 5407003-IDEAM),
2006; Valles et al., 2006; Carassou et al., 2009; Mellin and Pontón, 2009).

To date, there are no studies that have documented the relative abundance of cryptic fish assemblages in the estuarine systems of the Tropical Eastern Pacific (TEP) and particularly on the Pacific coast of Colombia. For most of the species that make up this community, the only information available is restricted to their original description, unique records, and lists of species from specific areas. Studies that address the ecology of cryptic fish in the TEP have been carried out in tidepools and coral reefs in Mexico and Colombia (Castellanos-Galindo et al., 2005, 2014; Balart et al., 2006; González-Cabello and Bellwood, 2009; Alzate et al., 2014). The cryptobenthic fish fauna of the TEP has a low species richness compared to other areas, which produces low functional redundancy among the species that make up these communities (GonzálezCabello and Bellwood, 2009). The above refers to the fact that few species play the same function in the ecosystem (e.g. feeding habits) (Loreau, 2004), so this function is vulnerable to disturbances. These characteristics make this community of organisms vulnerable to both anthropogenic and environmental impacts.

In the present work, the cryptobenthic fish community is documented for the first time in the marine protected area Málaga National Natural Park Bahía Málaga (Uramba NNP). It is also evaluated whether the structure of this community differs temporally and spatially in this place.

\section{STUDY AREA}

The Uramba NNP (3,953169 N-77,326456 W; Figure 1) is a marine protected area (MPA) located on the central coast of the Colombian Pacific. This bay was formed during tectonic events in the late Miocene-Holocene (Martínez and López-Ramos, 2011). It has an area of $470.94 \mathrm{~km}^{2}$. Estuarine conditions dominate in this area that has average depths of $12-15 \mathrm{~m}$. Also, it hosts a diversity of habitats that include mangroves, rocky coasts, mudflats, sandy beaches, and both soft and hard bottoms (CanteraKintz et al., 2013). Annual precipitation is one of the highest among the coastal areas of the Western Hemisphere, with an average of $7236 \pm 2033 \mathrm{~mm}$ between 1969 and 2015 (station $n .^{\circ}$ 5407003-IDEAM), with a period of lower rainfall between January and April ( $\tilde{x}=422 \mathrm{~mm} / \mathrm{month})$ and higher rainfall between May and December $(\tilde{x}=746 \mathrm{~mm} /$ 


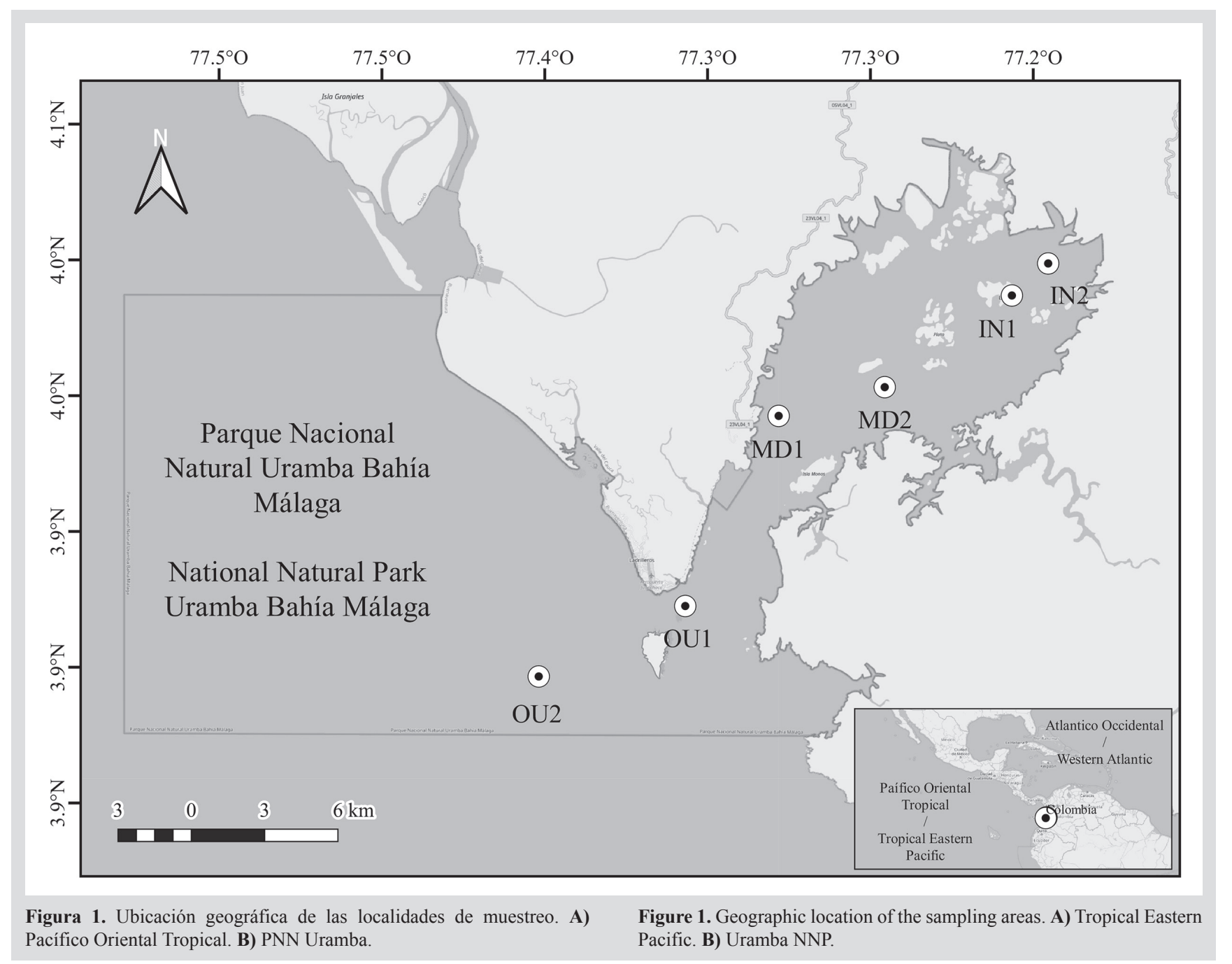

con un periodo de menores precipitaciones entre enero y abril $(\tilde{x}=422 \mathrm{~mm} / \mathrm{mes})$ y de mayores precipitaciones entre mayo y diciembre ( $\tilde{x}=746 \mathrm{~mm} / \mathrm{mes}$ ) (Castellanos-Galindo y Krumme, 2013). La temperatura superficial del mar es estable durante el año $\left(27-30{ }^{\circ} \mathrm{C}\right)$, mientras que los valores de salinidad varían entre 0 y 30 dependiendo de las corrientes mareales y la precipitación (Cantera-Kintz et al., 1998). Esta área se caracteriza por presentar un régimen macromareal semidiurno ( $c a .4 \mathrm{~m}$ de rango mareal).

\section{MATERIALES Y MÉTODOS}

\section{Muestreo}

Se utilizaron sustratos artificiales duros (SAD) como unidad de muestreo, los cuales contenían ladrillos y fragmentos de conchas recogidas en el área (concheros). Estos materiales fueron depositados en canastas plásticas $(35 \times 20 \times 18 \mathrm{~cm})$ y cubiertas con una malla con ojo de month) (Castellanos-Galindo and Krumme, 2013). Sea surface temperature is stable during the year $\left(27-30{ }^{\circ} \mathrm{C}\right)$, while salinity values vary between 0 and 30 depending on tidal currents and precipitation (Cantera-Kintz et al., 1998). This area is characterized by presenting a semi-diurnal macro-tidal regime (ca. $4 \mathrm{~m}$ tidal range).

\section{MATERIALS AND METHODS}

\section{Sampling}

Hard artificial substrates (SADs) were used as the sampling unit, which contained bricks and fragments of shells collected in the area (shells). These materials were deposited in plastic baskets $(35 \times 20 \times 18 \mathrm{~cm})$ and covered with a mesh with $2 \mathrm{~mm}$ openings (Figure 2). Six localities were chosen along the bay as follows: two in the inner zone (Silver: IN1, Coquero: IN2), two in the middle (Curichichi: MD1; The Negros: MD2) and two in the outer 
$2 \mathrm{~mm}$ (Figura 2). Se escogieron seis localidades a lo largo de la bahía de la siguiente manera: dos en la zona interna (La Plata: IN1; Coquero: IN2), dos en la media (Curichichi: MD1; Los Negros: MD2) y dos en la externa (Islote Morro Chiquito: OU1; Los Negritos: OU2) (Figura 1). El sustrato predominante de estas localidades es rocoso y está rodeado por fondos areno-fangosos. La profundidad a la cual estuvieron los SAD fue entre 3-7 m durante marea baja.

El muestreo se llevó a cabo entre junio de 2008 y agosto de 2009, periodo en el cual se realizaron siete salidas de campo aproximadamente cada dos meses. En la primera salida, tres SAD fueron ubicados en cada una de las localidades $(3 \mathrm{SAD} \times 6$ localidades $=18 \mathrm{SAD})$. En las siguientes salidas un número similar de SAD fue ubicado en cada localidad. Los SAD fueron recuperados después de la tercera salida de campo, cuando fue extraído el primer juego de $18 \mathrm{SAD}$. En las siguientes salidas, la recuperación y ubicación de SAD continuó. En promedio, los SAD estuvieron sumergidos por cinco meses $(\tilde{x} \pm$ d.e. $=145 \pm 19,4$ días $)$. En total se expusieron y recuperaron $90 \mathrm{SAD}$ durante todo el muestreo. Al ser recuperado, cada SAD fue levantado del fondo cuidadosamente y puesto al interior de canastas plásticas de mayor tamaño recubiertas con una malla con un ojo de menor tamaño mientras aún se encontraban en el agua. Después fueron llevadas a la superficie lentamente con ayuda de una bolsa recuperadora. Este procedimiento se realizó con el fin de evitar que algunos especímenes escaparan durante el proceso. zone (Morro Chiquito Islet: OU1; The Negritos: OU2) (Figure 1). The rocky substrate is predominant at these localities and is surrounded by sandy-muddy bottoms. The depths at which the SADs were placed ranged between 3-7 $\mathrm{m}$ during low tide.

The sampling was carried out between June 2008 and August 2009, a period in which seven field trips were carried out approximately every two months. In the first field trip, three SADs were located in each of the localities ( 3 SADs $\times 6$ localities $=18$ SADs $)$. In the following field trips, a similar number of SADs were located in each location. The SADs were recovered after the third field trip when the first set of 18 SADs was retrieved. In the following field trips, the recovery and location of SADs continued. On average, the SADs were submerged for five months $(\tilde{x} \pm$ s.d. $=145 \pm 19.4$ days $)$. In total, 90 SADs were exposed and recovered throughout the sampling. Upon being recovered, each SAD was carefully lifted from the bottom and placed inside larger plastic baskets covered with a mesh with smaller openings while still in the water. Later they were slowly brought to the surface with a recovery bag to prevent some specimens from escaping during the process.

After being extracted from the water, the SADs were placed in plastic trays with seawater. Once on land, they were carefully disarmed, searching for of fish and invertebrates, scraping the substrate by hand, and sifting the sediments accumulated in each unit. All fish were identified

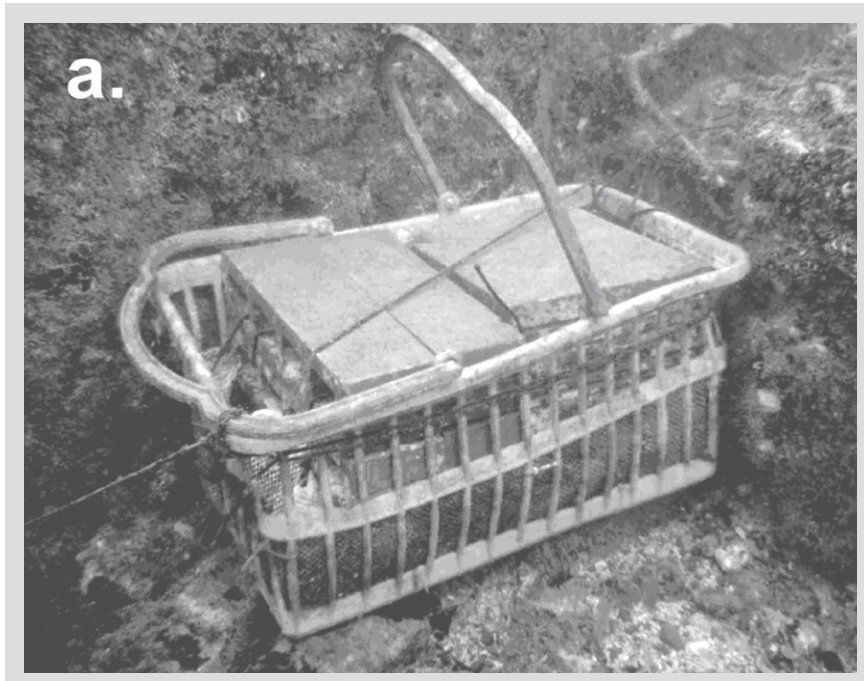

Figura 2. Sustratos artificiales duros (SAD) usados para la colecta de peces criptobentónicos en las seis localidades del PNN Uramba. A) SAD expuesto recientemente y B) SAD antes de ser recuperado, después de cinco meses.

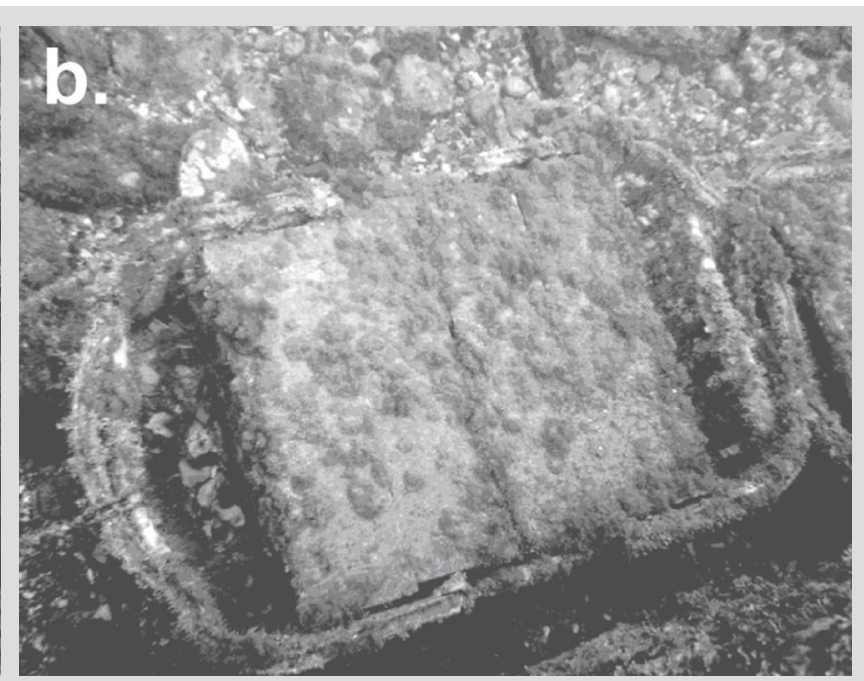

Figure 2. Hard artificial substrates (SADs) used for the collection of cryptobenthic fish in the six locations of the Uramba NNP. A) SAD recently exposed and $\mathbf{B})$ SAD before being recovered, after five months. 
Después de ser extraídos del agua, los SAD se dispusieron en bandejas plásticas con agua de mar. Una vez en tierra, fueron desarmados cuidadosamente en busca de peces e invertebrados, raspando a mano el sustrato y tamizando los sedimentos que se acumularon en cada unidad. Todos los peces fueron identificados al menor nivel taxonómico posible (siguiendo a Robertson y Allen, 2008) y se midió la longitud total (precisión $=0,01 \mathrm{~mm}$ ) y el peso (precisión $=0,001 \mathrm{~g}$ ). Algunos peces fueron preservados en formalina al $10 \%$ y transportados para ser depositados en la Colección de Referencia de Ictiología de la Universidad del Valle (CIRUV). Los datos de abundancia de los tres SAD para cada localidad fueron agrupados debido al bajo número de peces recolectados en cada una de las unidades experimentales. La densidad de peces se calculó al considerar el volumen de cada SAD $(35 \times 20 \times 18 \mathrm{~cm}=$ $0,0126 \mathrm{~m}^{3}$ o $0,07 \mathrm{~m}^{2}$ ). Se obtuvo la información sobre los hábitos alimentarios (HA) para cada especie registrada en Robertson y Allen (2008) y Froese y Pauly (2009).

Análisis de datos

Se utilizó el escalamiento multidimensional no métrico (nMDS) para explorar si existían patrones de agrupación entre localidades. Un análisis multivariado permutacional (PERMANOVA) fue usado para probar estadísticamente si la comunidad de peces criptobentónicos difería espacial (entre zonas) y temporalmente (entre meses). Además, se utilizó un análisis de similitud de porcentajes (SIMPER) para identificar las especies responsables de las diferencias entre zonas y meses cuando se encontraron diferencias significativas en el análisis PERMANOVA. Todos los análisis fueron realizados después de la transformación de los datos de abundancia a la raíz cuadrada (se excluyó un mes de muestreo para la localidad IN1 debido a la ausencia de peces). En todos los casos se usó el índice de similaridad de Bray-Curtis. Los análisis fueron realizados con el paquete vegan (Oksanen et al., 2019) del programa estadístico R (R Core Team, 2019).

\section{RESULTADOS}

Un total de 197 individuos pertenecientes a 26 especies y 11 familias de peces fueron recolectados durante todo el periodo de muestreo. De las especies encontradas, $50 \%$ corresponden a nuevos registros para el PNN Uramba (Figura 3, Tabla 1). Gobiidae, Labrisomidae y Gobiesocidae dominaron la comunidad en número de especies. Gobiidae $(43,7 \%$ del total de individuos) fue la familia to the lowest possible taxonomic level (following Robertson and Allen, 2008), total length (precision $=0.01 \mathrm{~mm}$ ) and weight (precision $=0.001 \mathrm{~g}$ ) were measured. Some fish were preserved in formalin (10\%) and transported to be deposited in the Ichthyology Reference Collection of the Universidad del Valle (CIRUV). The abundance data of the three SADs for each locality were grouped due to the low number of fish collected in each experimental unit. Fish density was calculated by considering the volume of each SAD $\left(35 \times 20 \times 18 \mathrm{~cm}=0.0126 \mathrm{~m}^{3}\right.$ or $\left.0.07 \mathrm{~m}^{2}\right)$. Information on feeding habits (HA) was obtained for each species recorded in Robertson and Allen (2008) and Froese and Pauly (2009).

Data analyses

Non-metric multidimensional scaling (nMDS) was used to explore whether clustering patterns existed between locations. A permutational multivariate analysis (PERMANOVA) was used to statistically test whether the cryptobenthic fish community differed spatially (between zones) and temporally (between months). Also, a percentage similarity analysis (SIMPER) was used to identify the species responsible for the differences between zones and months when significant differences were found in the PERMANOVA analysis. All the analyzes were carried out after transforming of the abundance data to the square root (one month of sampling was excluded for the IN1 locality due to the absence of fish). In all cases, the Bray-Curtis similarity index was used. The analyzes were performed with the vegan package (Oksanen et al., 2019) of the $\mathrm{R}$ statistical program (R Core Team, 2019).

\section{RESULTS}

A total of 197 individuals belonging to 26 species and 11 fish families were collected during the entire sampling period. Of the species found, $50 \%$ correspond to new records for the Uramba NNP (Figure 3, Table 1). Gobiidae, Labrisomidae, and Gobiesocidae dominated the community in number of species. Gobiidae ( $43.7 \%$ of all individuals) was the most representative family in terms of abundance, followed by Labrisomidae (22.3\%) and Muraenidae $(11.7 \%)$. The families with the least representativeness in the samples (less than three species and few individuals) were Balistidae, Serranidae, Pomacentridae, and Antennariidae. The yellow stalk Starksia fulva was the most abundant species, representing $16 \%$ of all individuals. The freckled worm goby Cerdale ionthas and the goby Gobulus 


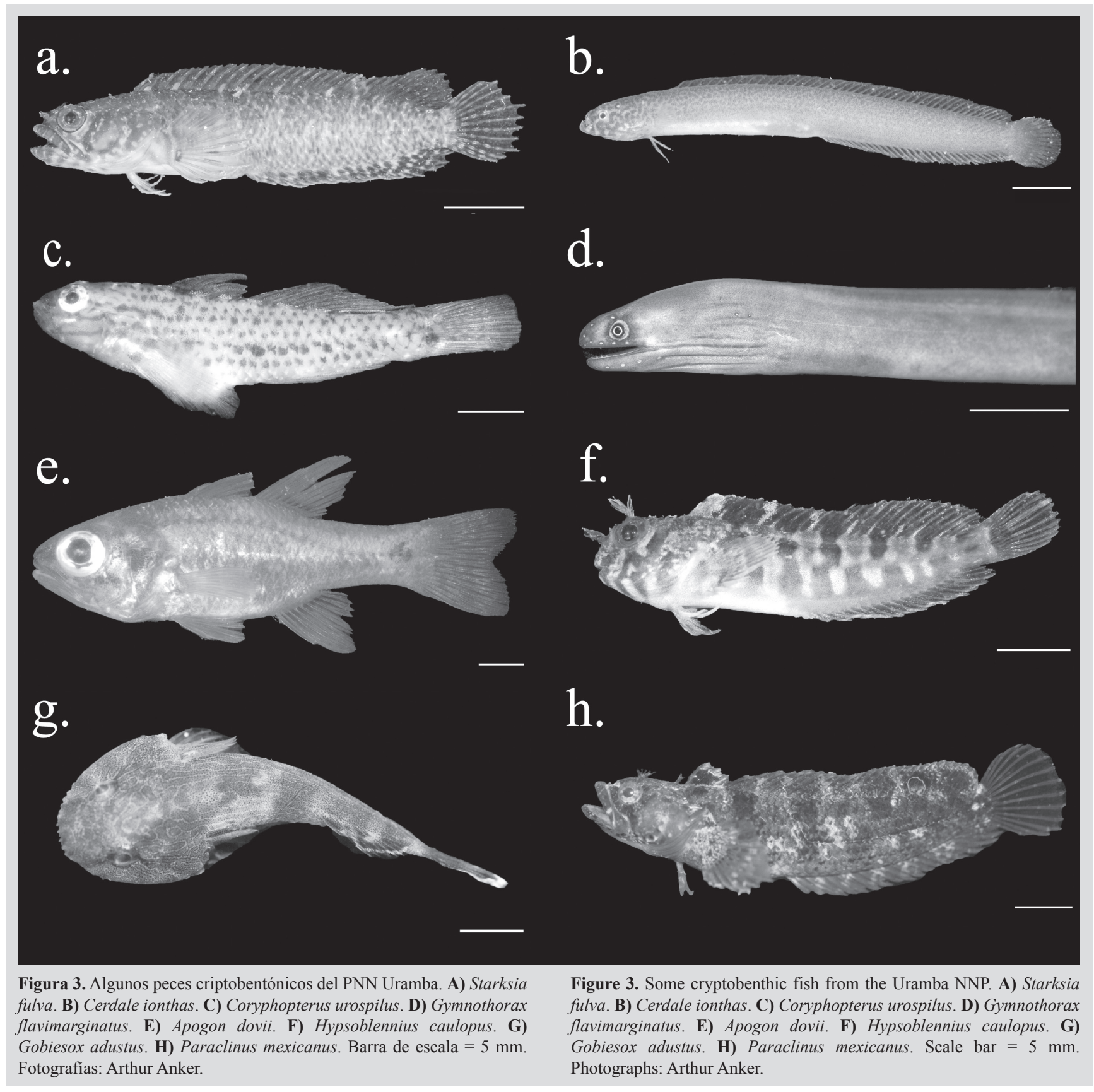

más representativa en cuanto a abundancia, seguida por Labrisomidae (22,3\%) y Muraenidae (11,7\%). Las familias con menor representatividad en las muestras (menos de tres especies y pocos individuos) fueron Balistidae, Serranidae, Pomacentridae y Antennariidae. El trambollito amarillo Starksia fulva fue la especie más abundante al representar $16 \%$ del total de individuos. El gobio gusano pecoso Cerdale ionthas y el gobio Gobulus hancocki representaron respectivamente $10 \%$ y $15 \%$ de la abundancia. Las especies restantes presentaron abundancias menores a $10 \%$ cada una. hancocki accounted for $10 \%$ and $15 \%$ of the abundance, respectively. The remaining species presented abundances less than $10 \%$ each.

The average fish density was $31.2 \pm 27.7$ ind $\mathrm{m}^{-2}$. For S. fulva and G. hanckoki, it was 5 ind $\mathrm{m}^{-2}$, while species with a single individual presented densities of 0.16 ind $\mathrm{m}^{-2}$ (Table 1). The average abundance was higher for OU2 $\left(12.8 \pm 10.5\right.$ ind $\left.\mathrm{m}^{-2}\right)$ and lower for OU1 $\left(2.6 \pm 2.3\right.$ ind $\left.\mathrm{m}^{-2}\right)$ and the average richness observed was higher for OU2

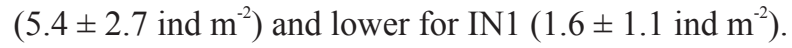


La densidad promedio de los peces fue de $31,2 \pm 27,7$ ind $\mathrm{m}^{-2}$. Para S. fulva y G. hanckoki fue de 5 ind $\mathrm{m}^{-2}$, mientras que especies con un solo individuo presentaron densidades de 0,16 ind $\mathrm{m}^{-2}$ (Tabla 1). La abundancia promedio fue mayor para OU2 $\left(12,8 \pm 10,5\right.$ ind $\left.\mathrm{m}^{-2}\right)$ y menor para OU1 $\left(2,6 \pm 2,3\right.$ ind $\left.\mathrm{m}^{-2}\right)$ y la riqueza promedio observada fue mayor para OU2 $\left(5,4 \pm 2,7\right.$ ind $\left.\mathrm{m}^{-2}\right)$ y menor para IN1 $\left(1,6 \pm 1,1\right.$ ind $\left.\mathrm{m}^{-2}\right)$.

En el nMDS se observó la separación de IN1 y OU2 de las demás localidades (Figura 4) y de la zona interna de las otras zonas. El análisis PERMANOVA de dos vías (zonas y meses) mostró que solo las zonas presentaron diferencias significativas y no se presentó interacción entre los factores (Tabla 2).
In the nMDS, the separation of IN1 and OU2 from the other localities (Figure 4) and from the internal zone of the other zones was observed. The two-way PERMANOVA analysis (zones and months) showed that only the zones presented significant differences, and there was no interaction between the factors (Table 2).

For the IN1 locality, the gobies Gobiosoma seminudum and C. ionthas accounted for $68.8 \%$ and $31.2 \%$ of the average Bray-Curtis similarities. For IN2 S. fulva was the most representative species, contributing $57.4 \%$ of the average Bray-Curtis similarity. Gobulus hancocki was the species that contributed the most to MD1 with $65 \%$ of the average similarity. Similarly, Coryphopterus urospilus was the most representative species for MD2 with a contribution

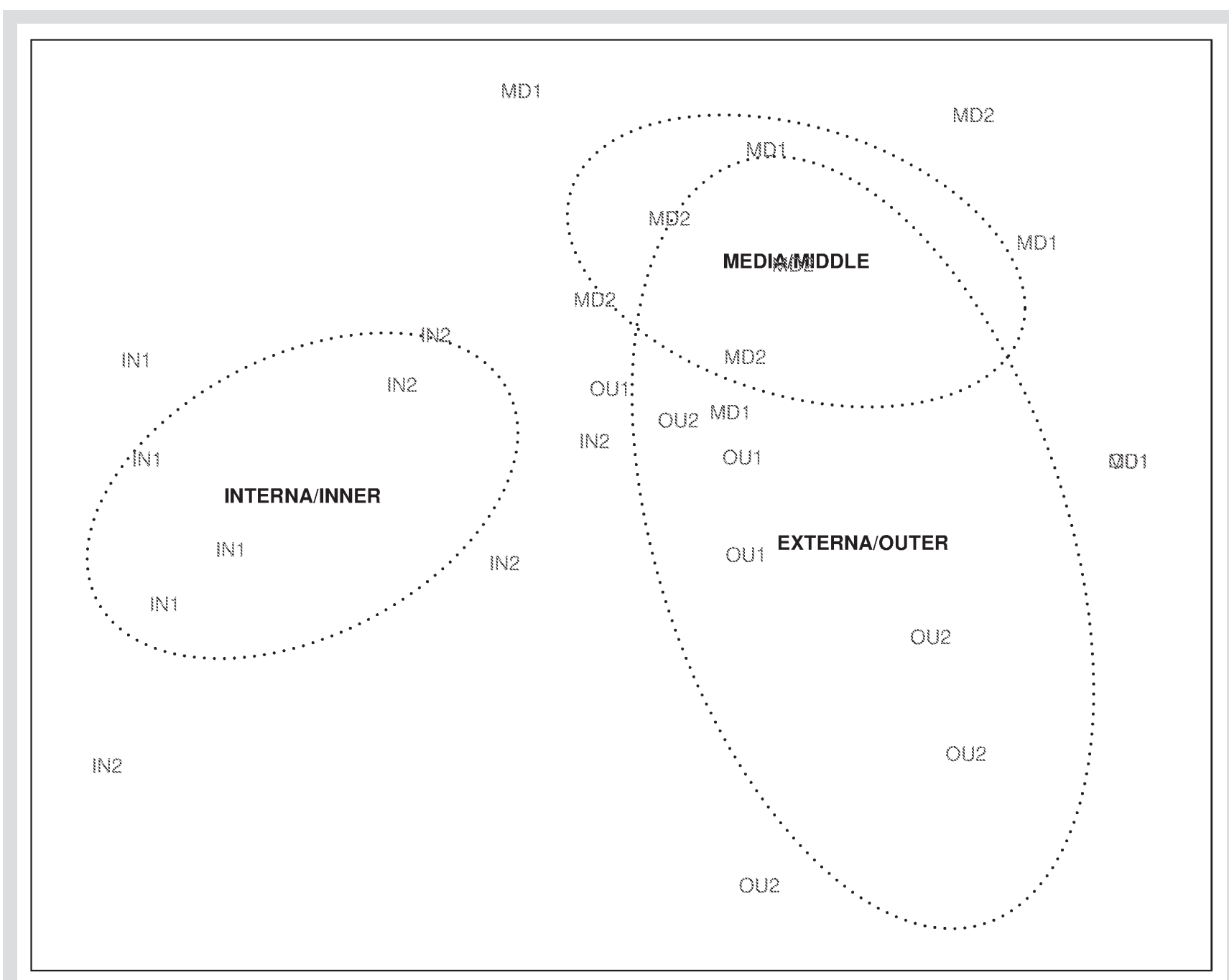

Stress: 0.09

Figura 4. Escalamiento multidimensional no métrico (nMDS) de las localidades y zonas de muestreo de peces criptobentónicos en el PNN Uramba (Pacífico Oriental Tropical).
Figure 4. Non-metric multidimensional scaling (nMDS) of the cryptobenthic fish localities and sampling areas in the Uramba NNP (Tropical Eastern Pacific). 
Tabla 1. Peces criptobentónicos recolectados en SAD (90) expuestos en las seis localidades del PNN Uramba en los cinco eventos de muestreo (2008-2009). Número total de individuos para cada especie (n) junto con el número de individuos medidos (en paréntesis). $\tilde{x} \pm$ d.e. $=$ Promedio \pm desviación estándar. $\mathrm{HA}=$ Hábitos alimentarios. $\mathrm{C}=$ Carnívoro. $\mathrm{P}=$ Planctívoro. O = Omnívoro (Robertson y Allen, 2008). FO: Frecuencia de ocurrencia. *Nuevos registros para el PNN Uramba. El listado se presenta de acuerdo con la clasificación propuesta por Betancur et al. (2017).
Table 1. Cryptobenthic fishes collected in SADs (90) were exposed in the six locations of the Uramba NNP in the five sampling events (2008-2009). Total number of individuals for each species (n) together with the number of individuals measured (in parentheses). $\tilde{x} \pm$ d.e. $=$ Average \pm standard deviation. $\mathrm{HA}=$ Feeding habits. $\mathrm{C}=$ Carnivore. $\mathrm{P}=$ Planktivorous. $\mathrm{O}=$ Omnivore (Robertson and Allen, 2008). FO: Frequency of occurrence. *New records for the Uramba NNP. The list is presented according to the classification proposed by Betancur et al. (2017).

\begin{tabular}{|c|c|c|c|c|c|c|c|c|c|}
\hline \multirow{2}{*}{ Especies/Species } & \multirow{2}{*}{ HA } & \multirow{2}{*}{$\mathbf{n}$} & \multirow{2}{*}{$\begin{array}{l}\text { Densidad/ } \\
\text { Density } \\
\text { (ind m }{ }^{-2} \text { ) }\end{array}$} & \multirow{2}{*}{$\begin{array}{l}\text { FO } \\
(\%)\end{array}$} & \multirow{2}{*}{$\begin{array}{c}\text { Biomasa/ } \\
\text { Biomass (g) }\end{array}$} & \multicolumn{2}{|c|}{$\begin{array}{l}\text { Longitud estándar/ } \\
\text { Standard lenght (mm) }\end{array}$} & \multicolumn{2}{|c|}{ Biomasa/Biomass (g) } \\
\hline & & & & & & $\tilde{x} \pm$ d.e. & $\begin{array}{l}\text { Rango/ } \\
\text { Range }\end{array}$ & $\tilde{x} \pm$ d.e. & $\begin{array}{l}\text { Rango/ } \\
\text { Range }\end{array}$ \\
\hline \multicolumn{10}{|c|}{ Muraenidae } \\
\hline $\begin{array}{l}\text { Gymnothorax castaneus (Jordan } \\
\text { \& Gilbert, } 1883 \text { ) }\end{array}$ & $\mathrm{C}$ & $1(1)$ & 0.16 & 3.3 & 2.26 & - & 133.8 & - & 2.26 \\
\hline $\begin{array}{l}\text { Gymnothorax flavimarginatus } \\
\text { (Rüppell, 1830)* }\end{array}$ & $\mathrm{C}$ & $11(6)$ & 1.74 & 13 & 1.98 & $48.2 \pm 25.3$ & $64.3-20$ & $0.33 \pm 0.37$ & $1.07-0.02$ \\
\hline $\begin{array}{l}\text { Muraena lentiginosa Jenyns, } \\
1842\end{array}$ & $\mathrm{C}$ & 11(1) & 1.74 & 17 & 0.58 & - & 71.7 & - & 0.58 \\
\hline \multicolumn{10}{|c|}{ Apogonidae } \\
\hline Apogon dovii Günther, 1862 & $P$ & $3(2)$ & 0.47 & 6.7 & 5.13 & 51.4 & $70.1-32.4$ & 2.57 & 4.74-0.39 \\
\hline \multicolumn{10}{|c|}{ Gobiidae } \\
\hline $\begin{array}{l}\text { Cerdale ionthas Jordan \& } \\
\text { Gilbert, } 1882 *\end{array}$ & $\mathrm{C}$ & $23(14)$ & 3.64 & 17 & 4.23 & $41.3 \pm 10.9$ & $61.1-26.1$ & $0.30 \pm 0.25$ & $0.92-0.05$ \\
\hline $\begin{array}{l}\text { Coryphopterus urospilus } \\
\text { Ginsburg, } 1938 *\end{array}$ & $\mathrm{C}$ & $14(12)$ & 2.22 & 20 & 5.63 & $37.3 \pm 5.4$ & $47.1-27.4$ & $0.47 \pm 0.28$ & $0.93-0.17$ \\
\hline $\begin{array}{l}\text { Gobiosoma nudum (Meek \& } \\
\text { Hildebrand, 1928) * }\end{array}$ & $\mathrm{C}$ & $7(2)$ & 1.11 & 13 & 0.36 & 20.4 & 26.1-14.8 & 0.18 & $0.35-0.02$ \\
\hline $\begin{array}{l}\text { Gobiosoma seminudum (Günther, } \\
\text { 1861)* }\end{array}$ & $\mathrm{C}$ & $13(13)$ & 2.06 & 23 & 11.21 & $38.0 \pm 9.6$ & $50.5-19.1$ & $0.86 \pm 0.61$ & $2.07-0.06$ \\
\hline $\begin{array}{l}\text { Gobulus hancocki Ginsburg, } \\
\text { 1938* }\end{array}$ & $\mathrm{C}$ & $29(27)$ & 4.59 & 47 & 1.21 & $19.2 \pm 6.0$ & $32.9-10.3$ & $0.04 \pm 0.05$ & $0.18-0.05$ \\
\hline \multicolumn{10}{|c|}{ Pomacentridae } \\
\hline Abudefduf troschelii (Gill, 1862) & $\mathrm{O}-\mathrm{P}$ & $1(1)$ & 0.16 & 3.3 & 8.01 & - & 65.4 & - & 8.01 \\
\hline Chromis atrilobata Gill, 1862 * & $\mathrm{P}$ & $1(1)$ & 0.16 & 3.3 & 1.48 & - & 55.2 & - & 1.48 \\
\hline \multicolumn{10}{|c|}{ Gobiesocidae } \\
\hline $\begin{array}{l}\text { Arcos rhodospilus (Günther, } \\
1864) *\end{array}$ & $\mathrm{C}$ & $4(3)$ & 0.63 & 6.7 & 0.45 & $19.1 \pm 2.2$ & 21.4-16.9 & $0.15 \pm 0.08$ & $0.23-0.09$ \\
\hline $\operatorname{Arcos} \mathrm{sp}$ & $\mathrm{O}$ & $2(0)$ & 0.32 & 6.7 & - & - & - & - & - \\
\hline $\begin{array}{l}\text { Gobiesox adustus Jordan \& } \\
\text { Gilbert, } 1882\end{array}$ & $\mathrm{C}$ & $2(2)$ & 0.32 & 6.7 & 0.36 & 36 & $62.8-9.3$ & 0.18 & $0.35-0.01$ \\
\hline Gobiesox sp. & $\mathrm{O}$ & $10(8)$ & 1.58 & 13 & 0.52 & $15.5 \pm 3.0$ & 19.4-11.9 & $0.06 \pm 0.04$ & $0.14-0.02$ \\
\hline \multicolumn{10}{|c|}{ Blenniidae } \\
\hline $\begin{array}{l}\text { Hypsoblennius caulopus (Gilbert, } \\
\text { 1898)* }\end{array}$ & $\mathrm{O}$ & $3(2)$ & 0.47 & 6.7 & 1.33 & 32.3 & $46.7-17.9$ & 0.67 & $1.25-0.08$ \\
\hline
\end{tabular}




\begin{tabular}{|c|c|c|c|c|c|c|c|c|c|}
\hline \multirow{2}{*}{ Especies/Species } & \multirow{2}{*}{ HA } & \multirow{2}{*}{$\mathbf{n}$} & \multirow{2}{*}{$\begin{array}{l}\text { Densidad/ } \\
\text { Density } \\
\left(\text { ind } \text { m }^{-2} \text { ) }\right.\end{array}$} & \multirow{2}{*}{$\begin{array}{c}\text { FO } \\
(\%)\end{array}$} & \multirow{2}{*}{$\begin{array}{c}\text { Biomasa/ } \\
\text { Biomass }(\mathrm{g})\end{array}$} & \multicolumn{2}{|c|}{$\begin{array}{l}\text { Longitud estándar/ } \\
\text { Standard lenght (mm) }\end{array}$} & \multicolumn{2}{|c|}{ Biomasa/Biomass (g) } \\
\hline & & & & & & $\tilde{x} \pm$ d.e. & $\begin{array}{l}\text { Rango/ } \\
\text { Range }\end{array}$ & $\tilde{x} \pm$ d.e. & $\begin{array}{l}\text { Rango/ } \\
\text { Range }\end{array}$ \\
\hline \multicolumn{10}{|c|}{ Labrisomidae } \\
\hline $\begin{array}{l}\text { Paraclinus mexicanus (Gilbert, } \\
\text { 1904) }\end{array}$ & $\mathrm{C}$ & $2(2)$ & 0.32 & 3.3 & 2.17 & 42.3 & $49.7-34.8$ & 1.08 & $1.71-0.46$ \\
\hline $\begin{array}{l}\text { Starksia fulva Rosenblatt \& } \\
\text { Taylor, } 1971 *\end{array}$ & $\mathrm{C}$ & $32(24)$ & 5.06 & 50 & 9.59 & $30.5 \pm 9.4$ & $44.8-13.0$ & $0.40 \pm 0.36$ & $1.38-0.02$ \\
\hline $\begin{array}{l}\text { Starksia posthon Rosenblatt \& } \\
\text { Taylor, } 1971 *\end{array}$ & $\mathrm{C}$ & $1(1)$ & 0.16 & 3.3 & 0.3 & - & 34.0 & - & 0.3 \\
\hline Starksia sp. & $\mathrm{C}$ & $9(9)$ & 1.42 & 17 & 2.65 & $25.5 \pm 13.2$ & $47.0-9.0$ & $0.29 \pm 0.41$ & $1.07-0.003$ \\
\hline \multicolumn{10}{|c|}{ Antennariidae } \\
\hline $\begin{array}{l}\text { Antennatus sanguineus (Gill, } \\
1863 \text { ) * }\end{array}$ & $\mathrm{C}$ & $1(1)$ & 0.16 & 3.3 & 3.31 & - & 41.1 & - & 3.31 \\
\hline $\begin{array}{l}\text { Antennatus strigatus (Gill, } \\
1863 \text { * }\end{array}$ & $\mathrm{C}$ & $1(1)$ & 0.16 & 3.3 & 1.75 & - & 32.2 & - & 1.75 \\
\hline \multicolumn{10}{|c|}{ Balistidae } \\
\hline $\begin{array}{l}\text { Pseudobalistes naufragium } \\
\text { (Jordan \& Starks, 1895) }\end{array}$ & $\mathrm{C}$ & $1(1)$ & 0.16 & 3.3 & 1.3 & - & 33.3 & - & 1.3 \\
\hline \multicolumn{10}{|c|}{ Serranidae } \\
\hline Epinephelus sp. & $\mathrm{C}$ & $1(1)$ & 0.16 & 3.3 & 5.68 & - & 75.7 & - & 5.68 \\
\hline Rypticus nigripinnis Gill, 1861 & $\mathrm{C}$ & $10(6)$ & 1.58 & 20 & 6.53 & $37.4 \pm 23.0$ & $74.9-11.0$ & $1.09 \pm 1.90$ & 4.93-0.02 \\
\hline \multicolumn{10}{|c|}{ Scorpaenidae } \\
\hline $\begin{array}{l}\text { Scorpaena mystes Jordan \& } \\
\text { Starks, } 1895\end{array}$ & $\mathrm{C}$ & $4(3)$ & 0.63 & 10 & 0.29 & $20.9 \pm 3.4$ & $24.0-17.3$ & $0.10 \pm 0.04$ & $0.13-0.06$ \\
\hline
\end{tabular}

Tabla 2. Resultados del análisis multivariado permutacional (PERMANOVA) de dos vías evaluando los efectos de las zonas y los meses en la comunidad de peces criptobentónicos en el PNN Uramba (Pacífico Oriental Tropical). gl: Grados de libertad. SC: Suma de cuadrados. MC: Media de cuadrados. P: Nivel de significancia. **: Significativo $(\mathrm{P}<0,05)$.
Table 2. Results of the two-way permutational multivariate analysis (PERMANOVA) evaluating the effects of the zones and the months in the cryptobenthic fish community in the Uramba NNP (Tropical Eastern Pacific). gl: Degrees of freedom. SC: Sum of squares. MC: Mean of squares. P: Level of significance. **: Significant $(\mathrm{P}<0.05)$.

\begin{tabular}{|l|c|c|c|c|c|}
\hline Fuente de variación/Variation source & gl & SC & MC & Pseudo-F (tabulado/tabulated) & P \\
\hline Zona/Zone & 2 & 2.6876 & 1.3438 & 4.0397 & $0.001 * *$ \\
\hline Mes/Month & 4 & 1.1653 & 0.2913 & 0.8758 & 0.676 \\
\hline Zona $\times$ mes/Zone $\times$ month & 8 & 1.9631 & 0.2454 & 0.916 \\
\hline Residuales/Residuals & 14 & 4.6571 & 0.3326 & \\
\hline Total & 28 & 10.4731 & & \\
\hline
\end{tabular}


Para la localidad IN1, los gobios Gobiosoma seminudum y $C$. ionthas representaron $68,8 \%$ y $31,2 \%$ de las similitudes Bray-Curtis promedio. Para IN2 S. fulva fue la especie más representativa al contribuir con $57,4 \%$ de la similitud Bray-Curtis promedio. Gobulus hancocki fue la especie que más contribuyó para MD1 con $65 \%$ de la similitud promedio. Del mismo modo, Coryphopterus urospilus fue la especie más representativa para MD2 con una contribución de $41,6 \%$ de la similitud de esta localidad. Las diferencias encontradas en la comunidad de peces criptobentónicos entre la zona interna y las otras dos zonas se deben a la presencia de C. ionthas, $G$. seminudum, S. fulva y G. hancocki. Finalmente, la especie más representativa para las localidades OU1 y OU2 de la zona externa fueron respectivamente $S$. fulva y la morena Gymnothorax flavimarginatus. Las especies mencionadas fueron responsables de las mayores contribuciones en las diferencias entre los pares de zonas al ser evaluadas por medio del análisis SIMPER (Tabla 3).

Tabla 3. Comparación entre pares de zonas usando el análisis SIMPER. Para cada comparación pareada se indica el promedio de la diferencia entre los conjuntos de especies (D) y las seis especies de peces criptobentónicos que contribuyen de mayor forma a estas diferencias. of $41.6 \%$ of the similarity of this locality. The differences found in the cryptobenthic fish community between the internal zone and the other two zones are due to C. ionthas, G. seminudum, S. fulva, and G. hancocki. Finally, the most representative species for the OU1 and OU2 localities of the external zone were S. fulva and the brunette Gymnothorax flavimarginatus, respectively. The mentioned species were responsible for the greatest contributions in the differences between the pairs of zones when evaluated utilizing the SIMPER analysis (Table 3).

\section{DISCUSSION}

The cryptobenthic fish community of the Uramba NNP presents similarities with the composition of fish families that have been found in the coral reefs of the Gulf of California (Balart et al., 2006; González-Cabello and Bellwood, 2009) and of the Panamanian Pacific (Enochs et al., 2011). In the Gulf of California, Tripterygiidae,

Table 3. Comparison between pairs of zones using SIMPER analysis. For each paired comparison, the average of the difference between the sets of species (D) and the six species of cryptobenthic fish that contribute more to these differences.

\begin{tabular}{|c|c|c|}
\hline & Zona interna/Internal zone & Zona media/Middle zone \\
\hline Zona media/Middle zone & $\begin{array}{l}\text { D: } 0.90 \\
\text { Cerdale ionthans: } 21.02 \\
\text { Gobiosoma seminudum: } 15.14 \\
\text { Starksia fulva: } 13.67 \\
\text { Gobulus hancocki: } 11.17 \\
\text { Coryphopterus urospilus: } 9.46 \\
\text { Rypticus nigripinis: } 7\end{array}$ & - \\
\hline Zona externa/External zone & $\begin{array}{l}\text { D: } 0.94 \\
\text { Cerdale ionthas: } 21.53 \\
\text { Gobiosoma seminudum: } 16.43 \\
\text { Starksia fulva: } 12.01 \\
\text { Gobulus hancocki: } 8.81 \\
\text { Muraena lentiginosa: } 7.1 \\
\text { Gymnothorax flavimarginatus: } 7.01\end{array}$ & $\begin{array}{l}\text { D: } 0.82 \\
\text { Starksia fulva: } 16.64 \\
\text { Gobulus hancocki: } 14.99 \\
\text { Coryphopterus urospilus: } 10.94 \\
\text { Rypticus nigripinis: } 8.94 \\
\text { Gymnothorax flavimarginatus: } 8.13 \\
\text { Muraena lentiginosa: } 8.12\end{array}$ \\
\hline
\end{tabular}

\section{DISCUSIÓN}

La comunidad de peces criptobentónicos del PNN Uramba presenta similitudes con la composición de familias que se han encontrado en los arrecifes coralinos del golfo de California (Balart et al., 2006; González-Cabello y Bellwood, 2009) y del Pacífico panameño (Enochs et al., 2011). En el golfo de California, Tripterygiidae, Gobiidae, Chaenopsidae y Labrisomidae
Gobiidae, Chaenopsidae, and Labrisomidae are the families with the highest number of species, while Chaenopsidae, Tripterygiidae, and Gobiidae are those with the highest abundances. In the Uramba NNP, Gobiidae and Labrisomidae are the dominant families in the cryptobenthic fish community both in richness and abundance, while Tripterygiidae and Chaenopsidae were not recorded. The absence of these families can be explained by the fact that many of the three-finned fish 
son las familias con mayor número de especies, mientras que Chaenopsidae, Tripterygiidae y Gobiidae son aquellas con mayores abundancias. En el PNN Uramba, Gobiidae y Labrisomidae son las familias dominantes en la comunidad de peces criptobentónicos tanto en riqueza como en abundancia, mientras que Tripterygiidae y Chaenopsidae no se registraron. La ausencia de estas familias puede ser explicada debido a que muchas de las especies de peces de tres aletas (Tripterygiidae) y los trambollines tubícolas (Chaenopsidae) tienen nichos ecológicos especializados que no estuvieron presentes en los SAD. Por ejemplo, en ambientes someros de las zonas media e interna de la bahía se pueden observar especies de Chaenopsidae como el trambollín de los cirripedios Acanthemblemaria hancocki Myers and Reid, 1936, en testas de balanos vacías en sustratos rocosos cercanos a los $\mathrm{SAD}$, así como individuos del pez de tres aletas Axoclinus lucillae Fowler, 1944 (Tripterygiidae) (información sin publicar por los autores) en charcos del intermareal rocoso de la estación más externa (OU2). Si bien en el PNN Uramba no existen arrecifes de coral consolidados como en el golfo de California o el Pacífico panameño, la presencia de comunidades de peces similares indica que la ocurrencia de algunos arrecifes rocosos en esta área protegida puede servir de hábitat para estas especies, ya que dichos arrecifes son un equivalente ecológico de los coralinos, con una estructura heterogénea donde los organismos pueden encontrar refugio, alimento e incluso cumplir el papel de guardería. Además, las especies encontradas, en su mayoría, son altamente tolerantes a las fluctuaciones en la salinidad propias de esta localidad del Pacífico colombiano.

En la costa Pacífica de Panamá se han simulado matrices arrecifales usando restos de esqueletos de corales pocillopóridos, en la cuales Glynn (2006) encontró a Gobulus hancocki entre las especies más abundantes. Sin embargo, el pez críptico más común en ese estudio fue el jaboncillo ocelado Pseudogramma thaumasia (Gilbert, 1900), el cual no fue encontrado en el PNN Uramba, probablemente debido a que esta especie prefiere sustratos duros en zonas de baja turbidez, situación que es poco común en esta AMP.

Desde la perspectiva de los grupos funcionales, la comunidad de peces criptobentónicos del PNN Uramba difiere del descrito para la Gran Barrera de Coral por Depczynski y Bellwood (2003). Estos autores documentaron la predominancia de carnívoros ( $c a .70 \%$ de las especies y $85 \%$ de los individuos encontrados en ese estudio) y detritívoros en la comunidad de peces criptobentónicos species (Tripterygiidae) and tube blennies (Chaenopsidae) have specialized ecological niches not present in SADs. For example, species of Chaenopsidae such as the barnacle blenny Acanthemblemaria hancocki Myers and Reid, 1936, can be observed in shallow environments of the middle and inner areas of the bay. Similarly, individuals of the three-finned fish Axoclinus lucillae Fowler, 1944 (Tripterygiidae) are found in rocky tidepools of the outermost station (OU2) (unpublished information from the authors). Although there are no consolidated coral reefs in the Uramba NNP as in the Gulf of California or the Panamanian Pacific, the presence of similar fish communities indicates that the occurrence of some rocky reefs in this protected area can serve as habitat for these species, as these reefs are an ecological equivalent to coral reefs, with a heterogeneous structure where organisms can find shelter, food and nursery areas. Also, most of the species found are highly tolerant to fluctuations in salinity typical of this locality in the Colombian Pacific.

On the Pacific coast of Panama, reef matrices have been simulated using skeletal remains of pocilloporid corals, in which Glynn (2006) found Gobulus hancocki among the most abundant species. However, the most common cryptic fish in this study was the black-spot reefbass Pseudogramma thaumasia (Gilbert, 1900), which was not found in the Uramba NNP, probably because this species prefers hard substrates in low turbidity areas, a situation that is rare in this MPA.

From functional groups' perspective, the cryptobenthic fish community of the Uramba NNP differs from that described for the Great Barrier Reef by Depczynski and Bellwood (2003). In Uramba NNP the cryptobenthic fish community is dominated by carnivores (ca. $70 \%$ of the species and $85 \%$ of the individuals found in this study). In contrast, in the Great Barrier Reef, both carnivores and detritivores are dominant. In the TEP, Glynn (2006) and González-Cabello and Bellwood (2009) found that carnivores and planktivores dominate, while detritivores are a minority component of this community. The differences in these trophic groups of cryptobenthic fish from these regions (Eastern Indo-Pacific and Tropical Eastern Pacific) may be due to the disparity in both areas' geological and environmental histories.

Los Negritos, the outermost locality in this study (OU2), is the one with the least impacted due to the drainage of fresh water and terrigenous sediments. The predominant substrate there is rocky and usually presents less turbidity 
en la Gran Barrera de Coral. En el POT, Glynn (2006) y González-Cabello y Bellwood (2009) encontraron que los carnívoros y planctívoros son dominantes, mientras que los detritívoros son un componente minoritario de esta comunidad de organismos. Las diferencias en estos grupos tróficos de los peces criptobentónicos que se encuentran en estas regiones (Indo-Pacífico Oriental y POT) puede deberse a la disparidad en las historias geológicas y ambientales de ambos lugares.

Los Negritos, la localidad más externa en este estudio (OU2) es la que presenta menores afectaciones por el drenaje de agua dulce y sedimentos terrígenos. El sustrato predominante allí es rocoso y usualmente presenta una menor turbidez en comparación con las demás zonas. Además, es considerada una de las zonas más biodiversas (Cantera-Kintz, 1991; Guevara-Fletcher et al., 2011) del PNN Uramba. La composición de familias en Los Negritos es similar a la que se ha observado en los charcos intermareales del Parque Nacional Natural Gorgona (Castellanos-Galindo et al., 2014), donde se pueden encontrar arrecifes coralinos adyacentes a la zona intermareal. Muraenidae es una familia dominante en los charcos intermareales en Gorgona, con seis especies que contribuyen significativamente a las densidades y la biomasa de estos ambientes costeros. Por su parte, G. flavimarginatus fue una de las especies que diferenció a OU2 de las demás localidades de esta área protegida. De forma similar, las especies de Gobiesocidae y Antennariidae estuvieron representadas, siendo exclusivas de esta estación de muestreo.

En contraste, IN1 fue dominada por C. ionthas y E. seminudus y se caracterizó por la menor riqueza de especies entre todas las localidades. Estas especies se observan comúnmente en planos lodosos en áreas de manglar cercanas a la localidad de muestreo, donde tienen un papel importante como depredadores de la red trófica de los ecosistemas de manglar. Esto se evidenció gracias al uso de isótopos estables (Medina-Contreras et al., 2018). La ubicación de IN1 en el canal principal del PNN Uramba se caracteriza por fuertes corrientes mareales y una mayor influencia de las condiciones estuarinas, donde la presencia de sedimentos terrígenos es alta y limita el asentamiento de los peces criptobentónicos. En relación con lo anterior, se observa que OU2 y IN1 tienen las mayores diferencias ambientales y en la composición de especies. Sin embargo, S. fulva y G. hancocki se encuentran en la mayoría de las localidades, lo que sugiere que son tolerantes a las condiciones dinámicas típicas de áreas estuarinas. compared to the other areas. Furthermore, it is considered one of the most biodiverse areas (Cantera-Kintz, 1991; Guevara-Fletcher et al., 2011) of the Uramba NNP. The composition of families in Los Negritos is similar to that observed in the tidalpools of the Gorgona National Natural Park (Castellanos-Galindo et al., 2014), where coral reefs can be found adjacent to the intertidal zone. Muraenidae is a dominant family in the tidalpools in Gorgona, with six species that contribute significantly to the fish densities and biomass of these coastal environments. In NPP Uramba, G. flavimarginatus (Muraenidae) was one of the species that differentiated OU2 from the other localities in this protected area. Similarly, species of Gobiesocidae and Antennariidae were represented, being exclusive to this sampling station.

In contrast, IN1 was dominated by $C$. ionthas and E. seminudus and was characterized by the lowest species richness among all localities. These species are commonly observed in mudflats in mangrove areas close to the sampling location, where they play an essential role as predators of the food web of mangrove ecosystems. This was evidenced using stable isotopes (Medina-Contreras et al., 2018). The location of IN1 in the main channel of the Uramba NNP is characterized by strong tidal currents and by a greater influence of estuarine conditions, where the presence of terrigenous sediments is high and limits the settlement of cryptobenthic fishes. Concerning the above, it is observed that OU2 and IN1 have the greatest environmental and species composition differences. However, species such as S. fulva and G. hancocki are found in most localities, suggesting that they are tolerant to the dynamic conditions typical of estuarine areas.

The proportion of new records for the study area indicates that SADs are an adequate tool for collecting organisms such as fishes that are not easily observed in visual censuses, and they also highlight the importance of the Uramba NNP as a biodiverse area. In the last fish species checklist in this area, 237 were recorded (CastellanosGalindo et al., 2006), these new records increase the total number of species diversity for the park by $5 \%$ (reaching 250 species). It is very likely that when sampling in other habitats of the Uramba NNP (e.g. mangroves) using alternative sampling methods that focus on the species that make up these cryptobenthic communities, the number of fish species registered in this protected area will increase. Preliminary work that has focused on the mangrove endofauna in different localities of the central 
La proporción de nuevos registros para el área de estudio indica que los SAD son una herramienta adecuada para la colecta de organismos como peces que no son observados fácilmente en los censos visuales y también resaltan la importancia del PNN Uramba como un área biodiversa. En el último listado de especies de peces de esta área se registraron 237 (Castellanos-Galindo et al., 2006). Estos nuevos registros incrementan en $5 \%$ el número total de la diversidad de especies para el parque (alcanzando 250). Es muy probable que en muestreos en otros hábitats del PNN Uramba (e.g. manglares), que utilicen métodos alternativos enfocados en las especies que componen estas comunidades, se incremente el número de especies de peces registradas en esta área protegida. Trabajos preliminares que se han centrado en la endofauna de los manglares en diferentes localidades de la costa central del Pacífico colombiano han revelado que la diversidad tanto de peces como de otros organismos como crustáceos es mayor de lo que tradicionalmente se ha creído (J.F. Lazarus, obs. pers.) y ha permitido encontrar nuevas especies para la ciencia (Anker y Lazarus, 2015a, 2015b, 2017). Lo anterior abre una nueva línea de investigación desde la cual se pueda conocer la diversidad de estos sistemas y evaluar cuál es el aporte de este componente de la fauna en las redes tróficas de los ecosistemas estuarinos.

Por otra parte, es probable que los peces demersales de mayor tamaño pudieran haber escapado de los SAD durante el proceso de recuperación, pero la mayoría de las especies criptobentónicas probablemente se encuentran representadas con este método de muestreo. Glynn (2006) encontró en Panamá que el número de especies de peces comunes entre censos visuales y sustratos artificiales es bajo. Algunos estudios en la Gran Barrera de Coral y en la costa de Nueva Zelanda también han demostrado que existe poca superposición de especies entre los censos visuales y los muestreos en los cuales se ha usado rotenona (Ackerman y Bellwood, 2000; Willis, 2001; Smith-Vaniz et al., 2006). Estructuras similares a los SAD han sido usadas frecuentemente para investigar los patrones de asentamiento de peces en una variedad de hábitats naturales y a diferentes escalas temporales (v. g. Lozano y Zapata, 2003; Mellin y Pontón, 2009). Zimmerman y Martin (2004) usaron un método similar que permitió recolectar de forma efectiva invertebrados arrecifales en el Caribe. Estos resultados permiten demostrar que el uso de los SAD es una alternativa económica, no invasiva y no destructiva que permite tener una muestra representativa de fauna criptobentónica, lo
Colombian Pacific coast has revealed that the diversity of both fish and other organisms such as crustaceans are more significant than what has traditionally been believed (J.F. Lazarus, pers. obs.) and have allowed finding new species for science (Anker and Lazarus, 2015a, 2015b, 2017). This opens a new line of research in which the diversity of these systems can be known. The contribution of this component of fauna to the food webs of estuarine ecosystems can be evaluated.

On the other hand, larger demersal fish could have escaped from the SADs during the recovery process, but most cryptobenthic species are probably represented by this sampling method. Glynn (2006) found in Panama that the number of common fish species between visual censuses and artificial substrates is low. Some studies in the Great Barrier Reef and off the coast of New Zealand have also shown a little overlap between visual censuses and surveys in which rotenone has been used (Ackerman and Bellwood, 2000; Willis, 2001; Smith-Vaniz et al., 2006). Structures similar to SADs have been used frequently to investigate the settlement patterns of fish in various of natural habitats and at different time scales (e.g. Lozano and Zapata, 2003; Mellin and Pontón, 2009). Zimmerman and Martin (2004) used a similar method that made it possible to collect reef invertebrates in the Caribbean effectively. These results allow demonstrating that the use of SADs is an economical, non-invasive, and non-destructive alternative that allows having a representative sample of cryptobenthic fauna, which facilitates the study of different ecological processes that occur in benthic communities. However, care must be taken when extrapolating the fish densities of the SADs to the fish densities observed in nature. This method can constitute an aggregation site for individuals in the natural environment dispersed due to the limited availability of suitable substrates.

The density of cryptobenthic fishes observed in the Uramba NNP $\left(31.2\right.$ ind $\left.\mathrm{m}^{-2}\right)$ is in the upper range compared to other fish communities studied with different sampling techniques (e.g. rotenone, visual censuses) in other regions of the world. For example, Depczynski and Bellwood (2003) used rotenone to study cryptobenthic fish in the Great Barrier Reef, finding densities of 11.43 ind $\mathrm{m}^{-2}$ (384 individuals in $33.6 \mathrm{~m}^{2}$ ). A similar situation occurred with González-Cabello and Bellwood (2009), who found that the density of cryptobenthic fish in the Gulf of California was 20.9 ind $\mathrm{m}^{-2}$. Therefore, it can be considered that the use of SADs is a simple and reliable 
que facilita estudiar diferentes procesos ecológicos que se presentan en las comunidades bentónicas. No obstante, se debe tener cuidado al extrapolar las densidades de peces de los SAD a las densidades de peces observadas en la naturaleza, ya que este método puede constituirse en un sitio de agregación de individuos que en el medio natural se encontrarían dispersos, debido a la disponibilidad limitada de sustratos adecuados.

La densidad de peces criptobentónicos observada en el PNN Uramba (31,2 ind $\mathrm{m}^{-2}$ ) se encuentra en el rango superior en comparación con otras comunidades de peces estudiadas con técnicas diferentes de muestreo (v. $g$. rotenona, censos visuales) en otras regiones del mundo. Por ejemplo, Depczynski y Bellwood (2003) utilizaron rotenona para estudiar los peces criptobentónicos en la Gran Barrera de Coral y encontraron densidades de 11,43 ind $\mathrm{m}^{-2}$ (384 individuos en 33,6 $\mathrm{m}^{2}$ ). Una situación similar ocurrió con González-Cabello y Bellwood (2009), quienes encontraron que la densidad de peces criptobentónicos en el golfo de California era de 20,9 ind $\mathrm{m}^{-2}$. Por lo tanto, se considera que el uso de los SAD es un método sencillo y confiable para realizar estudios a este grupo de organismos.

El presente estudio es uno de los primeros intentos por describir la estructura de las comunidades de peces criptobentónicos de áreas estuarinas en el Pacífico Oriental Tropical. Observaciones preliminares sobre la abundancia de estas especies y los ciclos de vida cortos de muchas de estas permiten suponer que juegan un papel importante en la dinámica trófica de los ecosistemas donde se encuentran (Brandl et al., 2019). Por ello, las interacciones tróficas con otros componentes de los ecosistemas presentes en el PNN Uramba merecen ser investigadas a profundidad (v.g. metabarcoding de contenido estomacal; Casey et al., 2019). En particular, la presencia de un número elevado de carnívoros en los SAD indica que estos sustratos bentónicos heterogéneos en el PNN Uramba proveen también un hábitat a una gran variedad de presas (invertebrados) de las cuales los peces pueden alimentarse.

El bajo potencial de la redundancia funcional, el alto endemismo y el aumento en la frecuencia de eventos ENSO y sus impactos ecológicos son las principales causas de por qué algunos taxa marinos en el POT están amenazados de extinción (Polidoro et al., 2012; Chasqui et al., 2017). Por ello es necesario entender cómo esta comunidad de peces criptobentónicos reacciona espacial y temporalmente a los cambios de las condiciones ambientales que se presentan en los hábitats costeros de la región (v. g. contaminación method to carry out studies on this group of organisms.

The present study is one of the first attempts to describe the structure of cryptobenthic fish communities in estuarine areas in the Tropical Eastern Pacific. Preliminary observations on the abundance of these species and the short life cycles of many of them indicate that they play an essential role in the ecosystems' trophic dynamics where they are found (Brandl et al., 2019). Therefore, the trophic interactions with other components of the ecosystems present in the Uramba NNP deserve to be investigated in-depth (e.g. metabarcoding of stomach content; Casey et al., 2019). In particular, the presence of a high number of carnivores in the SADs indicates that these heterogeneous benthic substrates in the Uramba NNP also provide a habitat for a great variety of prey (invertebrates) on which fishes can feed.

The low potential of functional redundancy, the high endemism, and the increase in the frequency of ENSO events and their ecological impacts are the main causes why some marine taxa in the TEP are threatened with extinction (Polidoro et al., 2012; Chasqui et al., 2017). Therefore, it is necessary to understand how this community of cryptobenthic fishes reacts spatially and temporally to changes in environmental conditions that occur in the coastal habitats of the region (e.g. pollution and infrastructure development). Comparing this group's response with others with greater functional redundancy (e.g. crustaceans, mollusks) could help understand the main mechanisms that keep marine ecosystems' function. Cryptobenthic fishes could then be used as a model to test how different anthropogenic and natural disturbances (e.g. ENSO) affect the functioning and resilience of ecosystems in this MPA. This study shows that the Uramba NNP is vital for the conservation of little-known marine fauna in Colombia.

\section{ACKNOWLEDGEMENTS}

This study was carried out as part of the project "Vulnerability of the marine and coastal ecosystems of Bay Málaga (Colombian Pacific): natural and anthropic threats" co-financed by Minciencias, Invemar, and the Universidad del Valle (contract $n .^{\circ} 1106-52128786$ ). The samples were obtained during the project "Biodiversity of vulnerable life stages of marine organisms in Bay Málaga (Colombian Pacific) as a conservation criterion" co-financed by Minciencias, Invemar, and Universidad del Valle (contract 
y desarrollo de infraestructura). Comparar la respuesta de este grupo con otros con una mayor redundancia funcional (v. g. crustáceos, moluscos) permitiría tener una idea de cuáles son los mecanismos necesarios para mantener en óptimas condiciones los ecosistemas marinos. Los peces criptobentónicos podrían entonces ser usados como un modelo para probar cómo diferentes perturbaciones antropogénicas y naturales (v. g. ENSO) afectan el funcionamiento y la resiliencia de los ecosistemas en esta AMP. Este estudio muestra que el PNN Uramba es de vital importancia para la conservación de fauna marina poco conocida de Colombia.

\section{AGRADECIMIENTOS}

Este estudio se realizó como parte del proyecto "Vulnerabilidad de los ecosistemas marinos y costeros de Bahía Málaga (Pacífico colombiano): amenazas naturales y antrópicas", cofinanciado por Minciencias, el Invemar y la Universidad del Valle (Contrato n. ${ }^{\circ}$ 1106-52128786). Las muestras fueron obtenidas durante el proyecto "Biodiversidad de estadios de vida vulnerable de organismos marinos en Bahía Málaga (Pacifico colombiano) como criterio de conservación", cofinanciado por Minciencias, Invemar y la Universidad del Valle (Contrato n. ${ }^{\circ}$ 1106405-20155). Durante el proceso de escritura, GACG fue financiado por el DAAD a través de una beca otorgada por CEMarin, al igual que JFL, quien contó con una beca del programa de formación doctoral de Minciencias. DMC fue financiada por el programa Jóvenes Investigadores e Innovadores de Minciencias (Contrato n. ${ }^{\circ}$ 970-2011) y apoyada por una beca doctoral (n. $\left.{ }^{\circ} 734084\right)$ del Consejo Nacional de Ciencia y Tecnología (Conacyt) de México y por la Beca de Estímulo Institucional de Formación de Investigadores BEIFI del Instituto Politécnico Nacional de México. Los autores agradecen al grupo de investigación Ecomanglares por su colaboración en la fase de campo, a E. Rubio por su colaboración y consejos durante el proceso de identificación de las especies de peces, a F.A. Zapata quien facilitó información sobre los peces criptobentónicos del Parque Nacional Natural Gorgona, a A. Anker quien amablemente proporcionó las fotos de los peces y dio el permiso para usarlas en esta publicación. Al Programa de Liderazgo en Conservación (CLP), a M. Fischer, a G. Kattan (q. e. p. d.), a A. Giraldo y a H. Rosenthal por sus valiosos comentarios a este manuscrito. n. $\left.{ }^{\circ} 1106-405-20155\right)$. During the writing process, GACG was financed by the DAAD through a scholarship granted by CEMarin, as well as JFL who had a scholarship from the doctoral training program of Minciencias. DMC was funded by the Minciencias Young Researchers and Innovators program (contract $\mathrm{n} .{ }^{\circ}$ 970-2011) and supported by a doctoral scholarship (n. ${ }^{\circ}$ 734084) from the National Council of Science and Technology (Conacyt) from Mexico and the Stimulus Grant Institutional Training of Researchers BEIFI of the National Polytechnic Institute from Mexico. The authors want to thank to the Ecomanglares research group for their collaboration in the field phase, to E. Rubio for his collaboration and advice during the process of identifying the fish species, to F.A. Zapata, who provided with information about the cryptobenthic fish of the Gorgona National Natural Park, to A. Anker who kindly provided with the photos of the fish and permitted to use them in this publication. To the Conservation Leadership Program (CLP), M. Fischer, G. Kattan (RIP), A. Giraldo and H. Rosenthal for their valuable comments on this manuscript. 


\section{BIBLIOGRAFÍA/LITERATURE CITED}

Ackerman, J.L. and D.R. Bellwood. 2000. Reef fish assemblages: a re-evaluation using enclosed rotenone stations. Mar. Ecol. Prog. Ser., 206: $227-237$. https://doi.org/10.3354/meps206227

Ackerman, J.L. and D.R. Bellwood. 2002. Comparative efficiency of clove oil and rotenone for sampling tropical reef fish assemblages. J. Fish Biol., 60: 893-901. https://doi.org/10.1111/j.1095-8649.2002.tb02416.x

Alzate, A., F.A. Zapata, and A. Giraldo. 2014. A comparison of visual and collection-based methods for assessing community structure of coral reef fishes in the Tropical Eastern Pacific. Rev. Biol. Trop., 62: 359-371. https://doi.org/10.15517/rbt.v62i0.16361

Anker, A. and J.F. Lazarus. 2015a. Description of two new associated infaunal decapod crustaceans (Axianassidae and Alpheidae) from the tropical eastern Pacific. Pap. Avulsos Zool., 55(8):115-129. https://doi.org/10.1590/0031-1049.2015.55.08

Anker, A. and J.F. Lazarus. 2015b. On two new species of the shrimp genus Salmoneus Holthuis, 1955 (Decapoda, Caridea, Alpheidae) from the tropical eastern Pacific. Zootaxa, 3957(5): 520-534. https://doi.org/10.11646/zootaxa.3957.5.2

Anker, A. and J.F. Lazarus. 2017. First finding of the shrimp genus Harperalpheus Felder \& Anker, 2007 in the eastern Pacific, with description of a new species from Bahía Málaga, Colombia (Malacostraca: Decapoda: Alpheidae). Zootaxa, 4329(2): 196-200. https://doi.org/10.11646/zootaxa.4329.2.7

Balart, E.F., A. González-Cabello, R.C. Romero-Ponce, A. Zayas-Álvarez, M. Calderón-Parra, L. Campos-Dávila, and L.T. Findley. 2006. Length-weight relationships of cryptic reef fishes from southwestern Gulf of California, Mexico. J. Appl. Ichthyol., 22: 6-318. https://doi.org/10.1111/j.14390426.2006.00670.x

Barletta, M., U. Saint-Paul, A. Barletta-Bergan, W. Ekau, and D. Schories. 2002. Spatial and temporal distribution of Myrophis punctatus (Ophichthidae) and associated fish fauna in a northern Brazilian intertidal mangrove forest. Hydrobiologia, 426: 65-74. https://doi.org/10.1023/A:1003939000270

Beldade, R. and E.J. Gonçalves. 2007. An interference visual census technique applied to cryptobenthic fish assemblages. Vie et Milieu, 57: 61-65.

Betancur, R., E.O. Wiley, G. Arriata, A. Acero, N. Bailly, M. Miya, G. Lecointre, and G. Ortí. 2017. Phylogenetic classification of bony fishes. BMC Evol. Biol., 17: 162. https://doi.org/10.1186/s12862-017-0958-3

Brandl, S.J., L. Tornabene, C.H.R. Goatley, J.M. Casey, R.A. Morais, I.M. Côté, C.C. Baldwin, V. Parravicini, N.M.D. Schiettekatte, and D.R. Bellwood. 2019. Demographic dynamics of the smallest marine vertebrate fuel coral reef ecosystem functioning. Science, 364: 1189-92. https://doi.org/10.1126/ science.aav3384

Cantera-Kintz, J.R. 1991. Etude structurale des mangroves et des peuplements macrobenthiques littoraux de deux baies du Pacifique colombien (Malaga et Buenaventura), rapport avec les conditions du milieu et les perturbations anthropiques. Ph.D. Thesis, Univ Aix-Marseille II, Marseille. 429 p.

Cantera-Kintz, J.R., R. Neira y C. Ricaurte. 1998. Bioerosión en la costa pacífica colombiana: un estudio sobre la biodiversidad, la ecología y el impacto de los animales destructores de los acantilados rocosos. Fondo FEN Colombia, Bogotá. 135 p.

Cantera-Kintz, J.R., E. Londoño-Cruz, L.M. Mejía-Ladino, L. Herrera-Orozco, C.A. Satizabal, and N. Uribe-Castañeda. 2013. Environmental issues of a Marine Protected Area in a tectonic estuary in the Tropical Eastern Pacific: Uramba (Malaga Bay, Colombia). context, biodiversity, threats and challenges. J. Water Res. Prot., 5: 1037-1047. https://doi.org/10.4236/jwarp.2013.511109

Carassou, L., C. Mellin, and D. Pontón. 2009. Assessing the diversity and abundances of larvae and juveniles of coral reef fish: a synthesis of six sampling techniques. Biodivers. Conserv., 18: 355-371. https://doi.org/10.1007/s10531-008-9492-3

Casey J.M., C.P. Meyer, F. Morat, S.J. Brandl, S. Planes, and V. Parravicini. 2019. Reconstructing hyperdiverse food webs: gut content metabarcoding as a tool to disentangle trophic interactions on coral reefs. Methods Ecol. Evol., 10: 1157-1170. https://doi.org/10.1111/2041-210X.13206

Castellanos-Galindo, G.A. and U. Krumme. 2013. Tidal, diel and seasonal effects on intertidal mangrove fish in a high-rainfall area of the Tropical Eastern Pacific. Mar. Ecol. Prog. Ser., 494: 249-265. https://doi.org/10.3354/meps10512

Castellanos-Galindo, G.A., A. Giraldo, and E.A. Rubio. 2005. Community structure of an assemblage of tidepool fishes on a Tropical Eastern Pacific rocky shore, Colombia. J. Fish Biol., 67: 392-408. https://doi.org/10.1111/j.0022-1112.2005.00735.x

Castellanos-Galindo G.A., J.A. Caicedo-Pantoja, L.M. Mejía-Ladino y E. Rubio. 2006. Peces marinos y estuarinos de Bahía Málaga, Valle del Cauca, Pacífico colombiano. Biota Colomb., 7(2): 263-282.

Castellanos-Galindo, G.A., A. Giraldo, and F.A. Zapata. 2014. Tidepool fish assemblages of Gorgona Island, Colombian Pacific coast: a local and regional comparison. Rev. Biol. Trop., 62: 373-390.

Chasqui L., A. Polanco, A. Acero P., P.A. Mejía-Falla, A. Navia, L.A. Zapata y J.P. Caldas (Eds). 2017. Libro rojo de peces marinos de Colombia. Instituto de Investigaciones Marinas y Costeras Invemar y Ministerio de Ambiente y Desarrollo Sostenible, Santa Marta. 552 p. 
Depczynski, M. and D.R. Bellwood. 2003. The role of cryptobenthic reef fishes in coral reef trophodynamics. Mar. Ecol. Prog. Ser., 256: 183-191. https:// doi.org/10.3354/meps 256183

Enochs, I.C., L.T. Toth, V.W. Brandtneris, J.C. Afflerbach, and D.P. Manzello. 2011. Environmental determinants of motile cryptofauna on an eastern Pacific coral reef. Mar. Ecol. Prog., 438: 105-118. https://doi.org/10.3354/meps09259

Froese, R. and D. Pauly. 2019. FishBase. https://www.fishbase.se 15/11/2019.

Glynn, P.W. 2006. Fish utilization of simulated coral reef frameworks versus eroded rubble substrates off Panama, eastern Pacific. Proc. Coral Reef Symp., 1: $250-256$.

González-Cabello, A. and D.R. Bellwood. 2009. Local ecological impacts of regional biodiversity on reef fish assemblages. J. Biogeogr., 36: 1129-1137. https://doi.org/10.1111/j.1365-2699.2008.02065.x

Guevara-Fletcher, C.E., J.R. Cantera-Kintz, L.M. Mejía-Ladino, and F.A. Cortes. 2011. Benthic macrofauna associated with submerged bottoms of a tectonic estuary in Tropical Eastern Pacific. J. Mar. Sci., 2011: 1-13. https://doi.org/10.1155/2011/193759

Loreau, M. 2004. Does functional redundancy exist? Oikos, 104(3): 606-611. https://doi.org/10.1111/j.0030-1299.2004.12685.x

Lozano, S. and F.A. Zapata. 2003. Short-term temporal patterns of early recruitment of coral reef fishes in the Tropical Eastern Pacific. Mar. Biol., 142: 399-409. https://doi.org/10.1007/s00227-002-0948-9

Martínez, J.O. and E. López-Ramos. 2011. High-resolution seismic stratigraphy of the late Neogene of the central sector of the Colombian Pacific continental shelf: a seismic expression of an active continental margin. J. S. Am. Earth. Sci., 31: 28-44. https://doi.org/10.1016/j.jsames.2010.09.003

Medina-Contreras, D., J.R. Cantera-Kintz, A. Sánchez-González, and E. Mancera. 2018. Food web structure and trophic relations in a riverine mangrove system in the tropical eastern Pacific, central coast of Colombia. Estuaries Coast, 41(5): 1511-1521. https://doi.org/10.1007/s12237-017-0350-y

Mellin, C. and D. Pontón. 2009. Assemblages of reef fish settling on artificial substrates: effect of ambient habitat over two temporal scales. Mar. Freshwater. Res., 60: 1285-1297. https://doi.org/10.1071/MF08319

Oksanen, J.F., G. Blanchet, M. Friendly, R. Kindt, P. Legendre, D. McGlinn, P.R. Minchin, R.B. O’Hara, G.L. Simpson, P. Solymos, M.H.H. Stevens, E. Szoecs, and H. Wagner. 2019. vegan: community ecology package. R package version 2.5-6. https://CRAN.R-project.org/package=vegan 20/02/2020.

Polidoro, B., T. Brooks, K.E. Carpenter, G.J. Edgar, S. Henderson, J. Sanciangco, and D.R. Robertson. 2012. Patterns of extinction risk and threat for marine vertebrates and habitat-forming species in the Tropical Eastern Pacific. Mar. Ecol. Prog. Ser., 448: 93-104. https://doi.org/10.3354/meps09545

R Core Team. 2019. R: a language and environment for statistical computing. https://www.R-project.org 05/12/2019.

Ransome, E., J.B. Geller, M. Timmers, M. Leray, A. Mahardini, A. Sembiring, A.G. Collins, and C. Meyer, C.P. (2017). The importance of standardization for biodiversity comparisons: a case study using autonomous reef monitoring structures (ARMS) and metabarcoding to measure cryptic diversity on Mo'orea coral reefs, French Polynesia. PloS ONE, 12(4), e0175066. https://doi.org/10.1371/journal.pone.0175066

Robertson, D.R. and G.R. Allen. 2008. Shorefishes of the Tropical Eastern Pacific online information system. Smithsonian Tropical Research Institute, Balboa. https://biogeodb.stri.si.edu/sftep 05/10/2009.

Robertson, D.R. and W.F. Smith-Vaniz. 2008. Rotenone: an essential but demonized tool for assessing marine fish biodiversity. Bioscience, 58(2): 165-170. https://doi.org/10.1641/B580211

Robertson, D.R., G.D. Green, and C.B. Victor. 1988. Temporal coupling of production and recruitment of larvae of a Caribbean reef fish. Ecology, 69: 370381. https://doi.org/10.2307/1940435

Smith-Vaniz, W.F., H.L. Jelks, and L.A. Rocha. 2006. Relevance of cryptic fishes in biodiversity assessments: a case study at Buck Island Reef National Monument, St. Croix. Bull. Mar. Sci., 79: 17-48.

Valles, H., D.L. Kramer, and W. Hunte. 2006. A standard unit for monitoring recruitment of fishes to coral reef rubble. J. Exp. Mar. Biol. Ecol., 336: 171-183. https://doi.org/10.1016/j.jembe.2006.05.005

Willis, T.J. 2001. Visual census methods underestimate density and diversity of cryptic reef fishes. J. Fish Biol., 59: 1408-1411. https://doi.org/10.1006/ jfbi.2001.1721

Zimmerman, T.L. and J.W. Martin. 2004. Artificial reef matrix structures (ARMS): an inexpensive and effective method for collecting coral reef-associated invertebrates. Gulf Caribb. Res., 16: 59-6. https://doi.org/10.18785/gcr.1601.08 